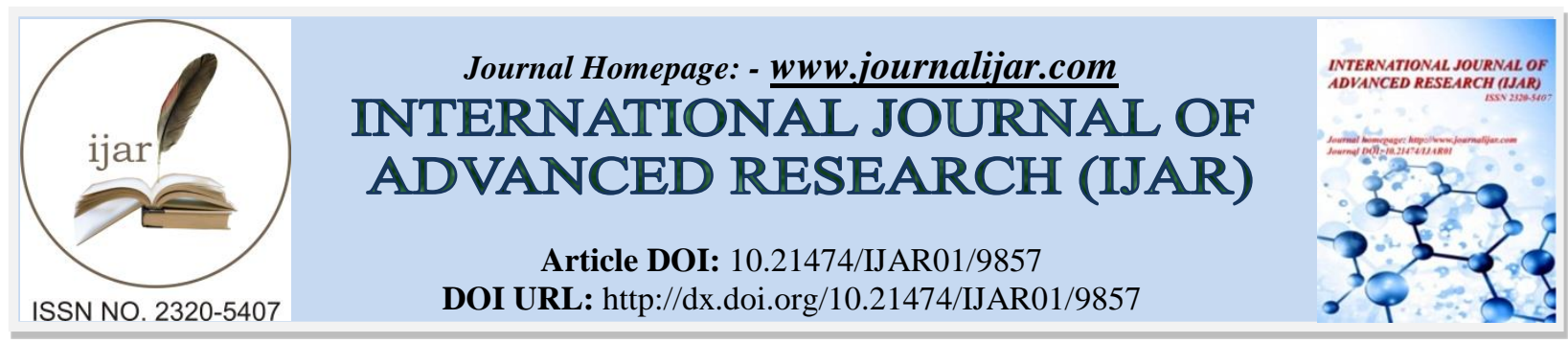

RESEARCH ARTICLE

\title{
SOIL MAPPING OF WEST MENIA AREA, EGYPT USING REMOTE SENSING AND GIS TECHNIQUES.
}

Ismail M., El Ghonamey Y. K. and Ganzour Shimaa K.

Soil, Water and Environment Research Institute.

\section{Manuscript Info}

\section{Manuscript History}

Received: 08 August 2019

Final Accepted: 10 September 2019

Published: October 2019

Key words:-

Soil Mapping, GIS, Remote Sensing, Egypt .

\begin{abstract}
The Western Menia area represents one of the highest priority areas for future development in the country. The studied area is located between $27^{\circ} 53^{\prime} \quad 20.11^{\prime \prime}-27^{\circ} 58^{\prime} \quad 48.34^{\prime \prime}$ North and $30^{\circ} 06^{\prime} \quad 41.53^{\prime \prime}-30^{\circ} 13^{\prime}$ 6.57" East and represents an area of about 9078 Feddans.

Using geological map, Digital Elevation Model (DEM) and visual interpretation of satellite data, a physiographic soil map was produced to present mapping units of the studied area. The area under investigation was classified into two landscapes, i.e. alluvial plain (4181 Feddans, $46.06 \%$ of the total studied area) and terraces (4897 Feddans, $53.94 \%$ of the total studied area)

This study aims to assess and mapping soil properties for salinity, sodicity, lime, gypsum, depth and texture.

Land capability was used to evaluate the soils of studied area. According to Sys model, the studied area was classified into four capability subclasses, i.e. $S_{2} x, S_{3} t, S_{3} d$ and $S_{3} d$, t. The soils of $S_{2} x$ have moderate limitations for agricultural crops, whereas texture is the most limiting factor (48.55\% of the total area). The most limiting factor of soils of $\mathrm{S}_{3} \mathrm{t}$ is topography (12.89\%), while the soils of $\mathrm{S}_{3} \mathrm{~d}(27.89 \%$ of the total studied area) whereas the depth is the most limiting factor. On other, hand the soils of $\mathrm{S}_{3} \mathrm{~d}, \mathrm{t}$ ( $10.66 \%$ of the total studied area) whereas the depth and topography are the main limiting factor for agriculture.

Soil fertility maps were conducted for macronutrients and micronutrients.
\end{abstract}

Copy Right, IJAR, 2019,. All rights reserved.

\section{Introduction:-}

Desert and uninhabited land represent approximately 95\% of the total area of Egypt. Consequently, the majority of the population is concentrated around the Nile River. This unbalanced distribution of inhabitants causes serious social and economic problems, such as the fact that the ever-increasing population has resulted in a decrease in agricultural area per capita from 0.13 ha in 1947 to 0.05 ha in 2004 (FAO, 2005). This value

The studied area is considered as a main region that represents one of these promising land resources in the Western Desert of Egypt, which is needed for the agricultural development facing the pressure of the inevitable food requirement.

Corresponding Author:-Ismail M..

Address:-Soil, Water and Environment Research Institute. 
In recent years, thematic mapping has undergone a revolution as the result of advances in geographic information science and remote sensing. For soil mapping archived data is often sufficient and this is available at low cost (Green, 1992).

GIS was used to identify the potential for certain irrigated agriculture for some soils in Western Desert, Egypt (Ismail et al., 2012)

Green, 1992 stated that integration of Remote Sensing within a GIS database can decrease the cost, reduce the time and increase the detailed information gathered for soil survey. Particularly, the use of Digital Elevation Model (DEM) is important to derive landscape attributes that are utilized in land forms characterization (Brough, 1986)

Satellite remote sensing (RS) in conjunction with geographic information system (GIS), have been widely applied and recognized as a powerful and effective tools in analyzing land use categories (Ehlers et.al, 1990; Harris \& Veturea 1995 and Weng, 2001). GIS provide indispensable tools for decision makers. Both RS and GIS techniques are considered very important geometric tools, which are fully utilized in the developing countries (Arafat, 2003). The integration of remotely sensed data, GIS and spatial statistics provides useful tools for modeling variability to predict the distribution, presence, and pattern of soil characteristics (Kalkhan et al., 2000). The potential of the integrated approach in using GIS and RS data for quantitative land evaluation has been demonstrated by Martin \& Saha (2009).

Land capability is very important step in the reclamation process of the desert to determine the capability of soil cultivation to meet the requirement of the population. To make the evaluation were used by Sys rating systems a methodology produced by Sys et al. (1991). The Sys rating systems were suggested under the structure of the FAO Framework for Land Evaluation (FAO, 1976).

The objectives for this study are: (a) producing soil properties maps. (b) evaluating land capability in current and potential. (c) producing soil fertility maps.

\section{Materials And Methods:-}

\section{Location}

The Studied area is located between $27^{\circ} 53^{\prime} 20.11^{\prime \prime}-27^{\circ} 58^{\prime} 48.34^{\prime \prime}$ North and $30^{\circ} 06^{\prime} 41.53^{\prime \prime}-30^{\circ} 13^{\prime} 6.57^{\prime \prime}$ East and represents an area of about 9078 Feddans (1). 


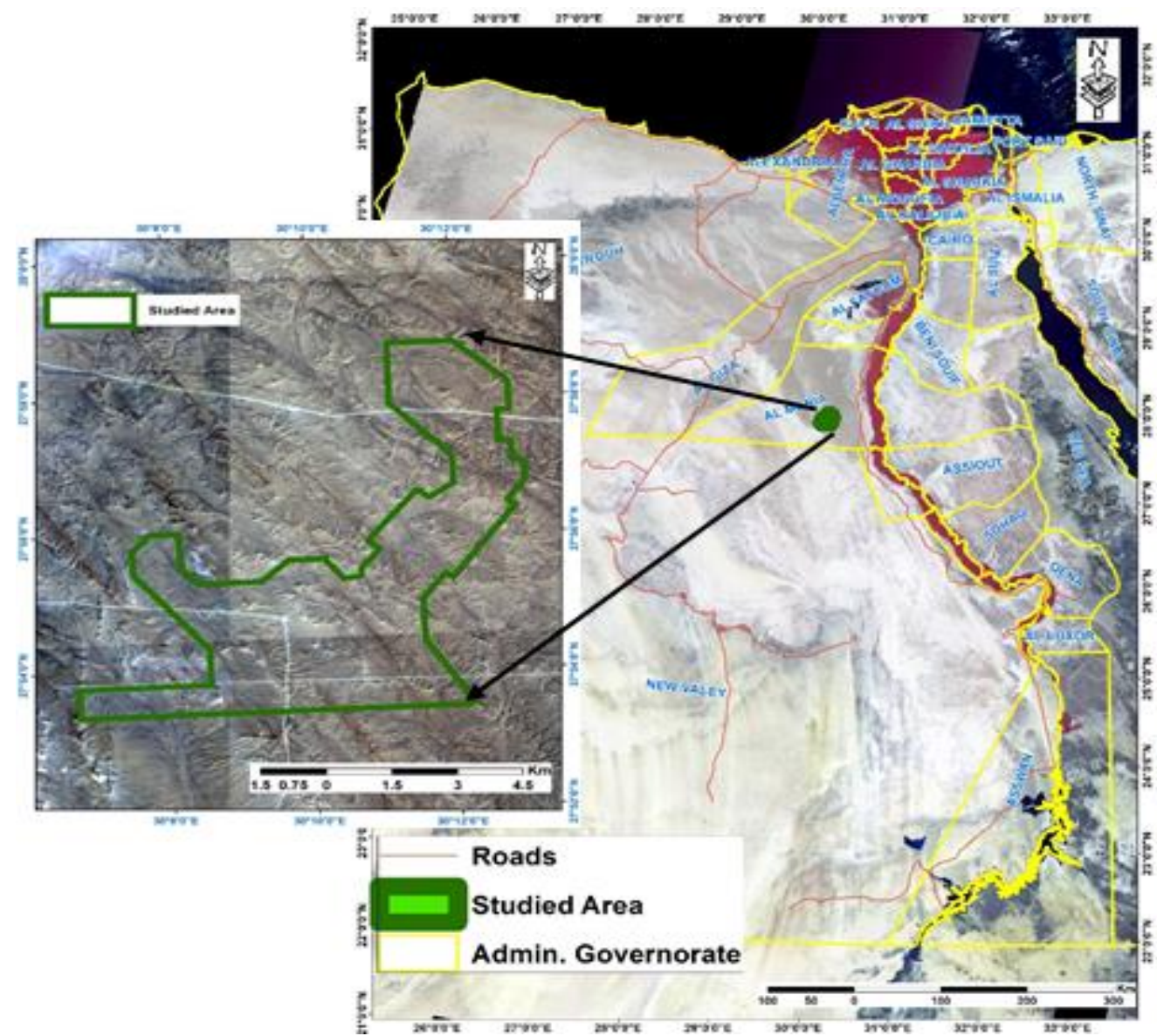

Figure 1:-Location map of the studied area.

\section{Climate}

As shown in Table1 the lowest value of rain (0.0) was in June, July and August while the highest value (3.43) in February. The maximum degree (38.77) was in July while the minimum degree (18.88) was in January. The lowest value of relative humidity $(24.81 \%)$ was in May while the highest value $(58.96 \%)$ in December. While The lowest value of wind speed $(2.07 \mathrm{~m} / \mathrm{s})$ was in November while the highest value $(3.61 \mathrm{~m} / \mathrm{s})$ in August.

Table 1:-Climatic characteristics of the study area (CLAC, 2018)

\begin{tabular}{|c|c|c|c|c|c|c|c|}
\hline & \multirow{2}{*}{$\begin{array}{l}\text { Rain } \\
\mathrm{mm} / \text { day }\end{array}$} & \multirow{2}{*}{$\begin{array}{l}\text { Wind } \\
\mathrm{m} / \mathrm{S}\end{array}$} & \multirow{2}{*}{ RH* } & \multicolumn{3}{|c|}{ Temperature C } & \multirow[b]{2}{*}{ SRAD* } \\
\hline & & & & Mean & Max & Min & \\
\hline January & 1.04 & 2.49 & 58.28 & 12.09 & 18.88 & 5.31 & 15.75 \\
\hline February & 3.43 & 2.16 & 42.54 & 17.18 & 24.38 & 9.97 & 13.37 \\
\hline March & 0.23 & 2.54 & 28.72 & 20.91 & 29.57 & 12.24 & 21.90 \\
\hline April & 0.04 & 2.99 & 27.41 & 23.44 & 31.88 & 15.00 & 24.48 \\
\hline May & 0.23 & 3.43 & 24.81 & 28.99 & 37.25 & 20.73 & 26.96 \\
\hline June & 0.00 & 3.48 & 25.07 & 30.69 & 38.57 & 22.80 & 29.44 \\
\hline July & 0.00 & 3.36 & 28.57 & 31.09 & 38.77 & 23.41 & 29.14 \\
\hline August & 0.00 & 3.61 & 33.06 & 31.01 & 38.47 & 23.55 & 27.30 \\
\hline September & 0.05 & 3.55 & 37.78 & 28.25 & 35.37 & 21.13 & 23.43 \\
\hline October & 0.25 & 2.95 & 40.40 & 24.82 & 31.69 & 17.95 & 19.63 \\
\hline November & 1.96 & 2.07 & 46.40 & 19.30 & 25.90 & 12.70 & 12.71 \\
\hline December & 1.29 & 2.44 & 58.96 & 13.70 & 19.87 & 7.52 & 14.10 \\
\hline Average and Sum & 8.52 & 2.92 & 37.67 & 23.45 & 30.88 & 16.03 & 21.52 \\
\hline
\end{tabular}

RH: Relative Humidity (\%)

SRAD: Solar Radiation $\left(\mathrm{MJ} / \mathrm{m}^{\wedge} 2 /\right.$ day $)$ 


\section{Geology:}

According to the geological map, produced by EGSA (1988) Moghra Formation is the main formation which represents an area of about $(74.9 \%)$ of the total studied area, covering the southern part, Gravely Platform Formation representing an area of $(25.1 \%)$ of the total studied area, which concentrated in the northern part of the studied area (Figure 2)

Fed. $=4200 \mathrm{~m}^{2}$

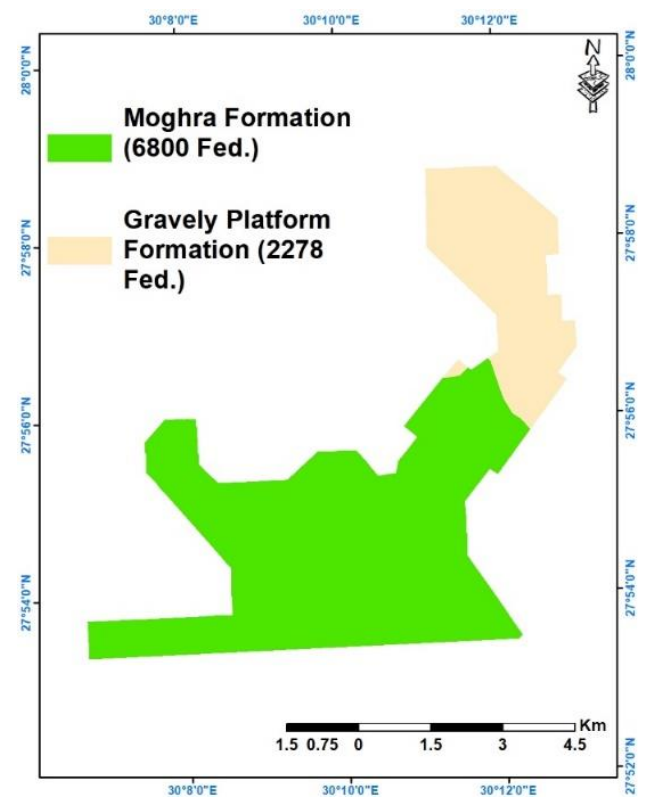

Figure 2:-Geological map of the studied area

\section{Satellite data:}

Data of sentinel 2 dated in August 2019 with spatial resolution of $10 \mathrm{~m}$ and spectral resolution of the bands 5, 3 and 2 were used for visual interpretation of the studied area.

Color enhancement operations were used to create new images which is increased the amount of information that can be visually interpreted from the data (Daels, 1986).

Universal Transverse Mercator projection (UTM) were used as main projection of all data and output maps (Daels, 1986).

The geo-statistical analysis techniques were used to create Digital Elevation Model (DEM) using the semivariogram parameters (Stein, 1998) of contour lines and spot heights.

\section{Field Work:}

Seventy-two soil profiles were collected to represent the soils of the studied area. Morphological descriptions of soil profiles were descriped according to FAO, 2006. Soil samples were collected for laboratory analyses.

Nine water samples were collected from the wells in the studied area. Water samples were analyzed to determine some chemical properties according to USDA (2004). These included the electric conductivity (ECe), soluble cations and anions and Sodium Adsorption Ratio (SAR). Suitability of water for irrigation was determine according to the limitations outlined by FAO (1985).

\section{Laboratory Analyses:}

The collected soil samples were air dried, crushed and prepared for laboratory analyses, to determine soil chemical and physical properties according to USDA, 2004 methods: particle size distribution, electrical conductivity (ECe) in the soil paste extract, calcium carbonate, gypsum, macronutrients and micronutrients. 


\section{Producing thematic maps}

The parameters of geo-statistical approach of the surface layer (seventy-two soil samples) were intered using Arc GIS 10.3 to produce soil salinity, soil sodicity, soil lime, soil gypsum, soil texture and soil depth maps. From the semi-variogram operation, it could be possible define which models fitted to the experimental semi-variogram values. The parameters of semi-variogram for best fitting a model were used to interpolate the thematic soil properties based on ordinary Kriging (Stein, 1998).

\section{Land Capability:}

Land capability for agriculture was assessed according to the method of Land Capability techniques using the rating tables of FAO (1985), Sys and Verheye (1978) and Sys et al. (1991). The method of land evaluation used according to the following equation:

$$
C i=\frac{t}{100} \times \frac{x}{100} \times \frac{d}{100} \times \frac{l}{100} \times \frac{g}{100} \times \frac{n}{100} \times 100
$$

Where:

$\mathrm{Ci}=$ Capability index $(\%), \mathrm{t}=$ Slope, $\mathrm{x}=$ Texture, $\mathrm{d}=$ Soil depth, $\mathrm{l}=$ Lime, $\mathrm{g}=$ Gypsum and $\mathrm{n}=$ Salinity and alkalinity

\section{Producing fertility maps}

According to geo-statistical analyses (Stein, 1998) the mas for macronutrients and micronutrients were produced using the classes in Table 2

Table 2:-The classes of macronutrients and micronutrients

\begin{tabular}{|l|l|l|l|}
\hline Class & Low & Medium & High \\
\hline Available Nitrogen $\left(\mathrm{mg} \mathrm{kg}^{-1}\right)$ & $<40$ & $40-80$ & $>80$ \\
\hline Available Phosphorus (mg kg & \\
\hline Available Potassium $\left(\mathrm{mg} \mathrm{kg}^{-1}\right)$ & $<5$ & $5-10$ & $>10$ \\
\hline Available Iron $\left(\mathrm{mg} \mathrm{kg}^{-1}\right)$ & $<200$ & $200-400$ & $>400$ \\
\hline Available Manganese (mg kg & & $>9$ \\
\hline Available Zinc $\left(\mathrm{mg} \mathrm{kg}^{-1}\right)$ & $<4.5$ & $4.5-9$ & $>5$ \\
\hline Available Copper $\left(\mathrm{mg} \mathrm{kg}^{-1}\right)$ & $<2$ & $2-5$ & $>2$ \\
\hline
\end{tabular}

The levels of macronutrients outlined by Page et al., (1982) and modified to suit the prevailing conditions in soils of Egypt as mentioned by Baker et al. (1999), The range of micronutrients Lindsay and Norvell, (1978) and Baker et al., (1999).

\section{Results and discussion:-}

\section{digital elevation model (dem)}

Figure 3 shows the height areas located in the middle side and the elevation ranged from 139 to 159 meter above sea level. The low areas located in the northern and western areas for the studied area as the elevation ranged between 120 and 133 meter above sea level.

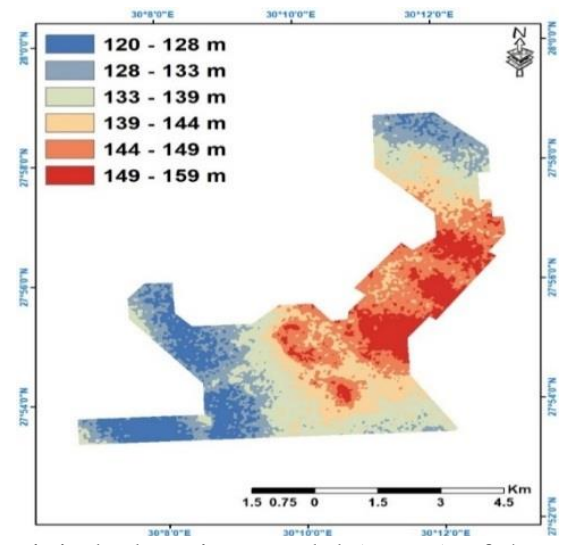

Figure 3:-Digital Elevation Model (DEM) of the studied area 


\section{Physiographic soil map of the studied area}

Based on sentinel-2 image taken during August 2019, digital elevation model (DEM), the topography and field check, the physiography of the studied area has been identified (Table 3). The obtained data in (Table 3) showed that the representative soil profiles vary in their characteristics mainly due to they have been developed on different landscape - land form- Relief , i.e. alluvial plain, and terraces (Figure 4) as shown in the following discussion.

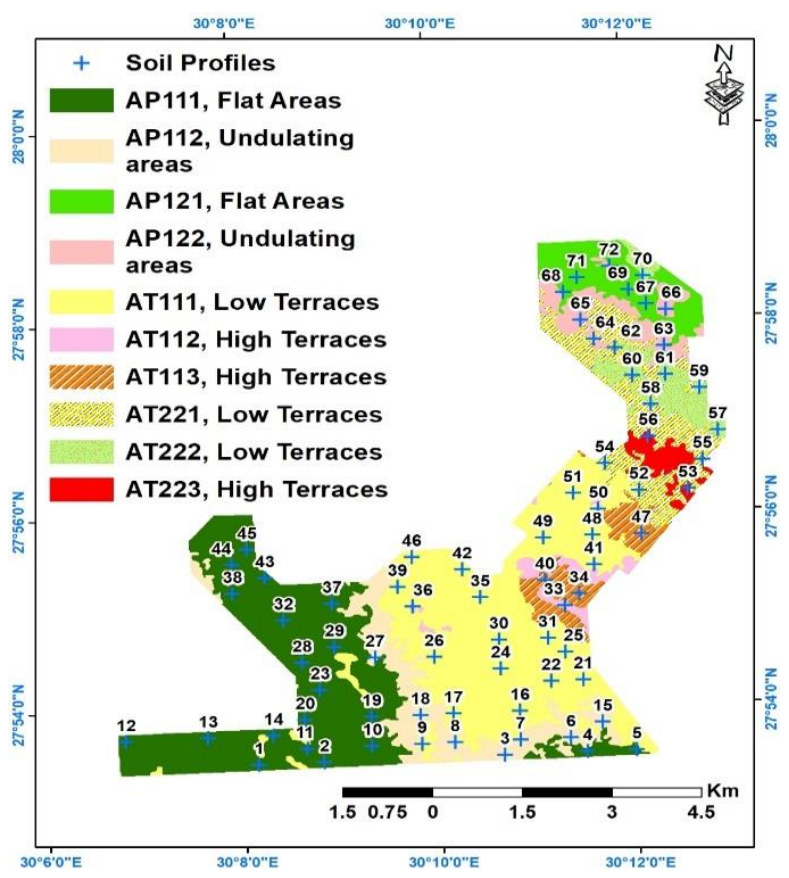

Figure 4:-Location of soil profiles on Physiographic soil map of the studied area

Table 3:-Physiographic soil map legend

\begin{tabular}{|c|c|c|c|c|c|c|}
\hline Landscape & Relief & Lithology & Landform & Code & $\begin{array}{l}\text { Area } \\
\text { Feddans }\end{array}$ & $\%$ \\
\hline \multirow[t]{4}{*}{$\begin{array}{l}\text { Alluvial } \\
\text { Plain }\end{array}$} & Almost Flat & \multirow[t]{2}{*}{ Moghra Formation } & Flat Areas & AP111 & 2389 & $\begin{array}{l}26.3 \\
2 \\
\end{array}$ \\
\hline & Undulating Areas & & Undulating areas & AP112 & 854 & 9.41 \\
\hline & Almost Flat & \multirow{2}{*}{$\begin{array}{l}\text { Gravely Platform } \\
\text { Formation }\end{array}$} & Flat Areas & AP121 & 551 & 6.07 \\
\hline & Undulating Areas & & Undulating areas & AP122 & 386 & 4.25 \\
\hline \multirow[t]{6}{*}{ Terraces } & $\begin{array}{l}\text { Gentaly Undulating } \\
\text { Areas }\end{array}$ & \multirow[t]{3}{*}{ Moghra Formation } & Low Terraces & AT111 & 2945 & $\begin{array}{l}32.4 \\
5\end{array}$ \\
\hline & & & High Terraces & AT112 & 184 & 2.02 \\
\hline & Undulating Areas & & High Terraces & AT113 & 393 & 4.33 \\
\hline & $\begin{array}{l}\text { Gently Undulating } \\
\text { Areas }\end{array}$ & \multirow[t]{4}{*}{$\begin{array}{l}\text { Gravely Platform } \\
\text { Formation }\end{array}$} & Low Terraces & AT221 & 796 & 8.76 \\
\hline & \multirow[t]{3}{*}{ Undulating Areas } & & Low Terraces & AT222 & 392 & 4.31 \\
\hline & & & High Terraces & AT223 & 188 & 2.08 \\
\hline Total & & & & & 9078 & 100 \\
\hline
\end{tabular}

\section{AP111 unit}

This soil is almost flat belong to alluvial plain and represented by 20 soil profiles Nos. 1, 2, 4, 5, 10, 11, 12, 13, 14, 19, 20, 23, 28, 29, 32, 37,38, 43, 44 and 45. The soil texture is Sandy Loam, $\mathrm{CaCO}_{3}$ between 2.62 and $23.2 \%$. EC value in $\mathrm{dS} \mathrm{m}^{-1}$ ranged from 1.3 to 15.9 and ESP from 3.3 to 18.6 (Table 4). Soil gypsum content vary between 1.1 and $14.2 \%$. 
Table 4:-some chemical, physical and fertility properties of the studied soil profiles for surface layer

\begin{tabular}{|c|c|c|c|c|c|c|c|c|c|c|c|c|c|}
\hline No & $\begin{array}{l}\text { Depth } \\
\text { (cm) }\end{array}$ & $\begin{array}{l}\text { EC } \\
\mathrm{dS} \mathrm{m}^{-1}\end{array}$ & Texture* & $\begin{array}{l}\mathrm{CaCO}_{3} \\
\%\end{array}$ & $\begin{array}{l}\text { Gyp. } \\
\%\end{array}$ & ESP & $\begin{array}{l}\mathbf{N} \\
* *\end{array}$ & $\begin{array}{l}\mathbf{P} \\
* *\end{array}$ & $\begin{array}{l}\mathbf{K} \\
* *\end{array}$ & $\begin{array}{l}\mathbf{F e} \\
* *\end{array}$ & $\begin{array}{l}\text { Mn } \\
* *\end{array}$ & $\begin{array}{l}\mathbf{Z n} \\
* *\end{array}$ & $\begin{array}{l}\mathbf{C u} \\
* *\end{array}$ \\
\hline 1 & 120 & 11.8 & SL & 16.4 & 12.6 & 18.6 & 78 & 0.07 & 185.1 & 11.26 & 1.5 & 0.85 & 0.096 \\
\hline 2 & 120 & 15.9 & SL & 8.8 & 5.7 & 9.5 & 78 & 0.82 & 139.4 & 11.31 & 1.54 & 0.79 & 0.098 \\
\hline 3 & 120 & 3.4 & LS & 4.4 & 5.6 & 7.3 & 74 & 0.31 & 121.6 & 11.59 & 1.53 & 0.7 & 0.097 \\
\hline 4 & 100 & 1.4 & LS & 2.6 & 1.1 & 5 & 56 & 0.26 & 53.6 & 11.48 & 1.53 & 0.9 & 0.097 \\
\hline 5 & 120 & 11.5 & SL & 15.3 & 10 & 17.2 & 49 & 3.49 & 45.6 & 0.77 & 0.17 & 0.01 & 0.003 \\
\hline 6 & 120 & 3.2 & LS & 5.5 & 3.2 & 7.2 & 56 & 1.78 & 232.1 & 3.31 & 0.9 & 0.19 & 0.004 \\
\hline 7 & 120 & 8.9 & LS & 8.4 & 7.3 & 17.1 & 35 & 1.48 & 61.8 & 2.27 & 0.94 & 0.08 & 0.003 \\
\hline 8 & 75 & 2.7 & LS & 8.8 & 5.3 & 7.1 & 33 & 1.28 & 37.8 & 2.29 & 0.96 & 0.01 & 0.004 \\
\hline 9 & 70 & 2.9 & LS & 14 & 5.1 & 7.1 & 63 & 1.87 & 117.2 & 2.27 & 0.99 & 0.01 & 0.002 \\
\hline 10 & 140 & 4.5 & SL & 13.1 & 6.7 & 3.3 & 63 & 1.57 & 95.4 & 2.35 & 0.99 & 0.05 & 0.002 \\
\hline 11 & 55 & 3.3 & SL & 5.5 & 14.2 & 6.5 & 63 & 1.23 & 74.2 & 2.41 & 1.02 & 0.09 & 0.002 \\
\hline 12 & 120 & 2.8 & SL & 14.3 & 6 & 10.3 & 53 & 1.78 & 63 & 2.47 & 1.03 & 0.01 & 0.002 \\
\hline 13 & 140 & 12.9 & SL & 13.9 & 5.5 & 18.6 & 64 & 1.6 & 70 & 2.53 & 1.07 & 0.01 & 0.002 \\
\hline 14 & 60 & 6.1 & SL & 7 & 5.4 & 5.1 & 60 & 1.72 & 70 & 2.52 & 1.1 & 0.01 & 0.002 \\
\hline 15 & 120 & 11.8 & SL & 8.1 & 7.2 & 27.6 & 66.8 & 0.59 & 70 & 2.57 & 1.15 & 0.08 & 0.002 \\
\hline 16 & 110 & 3.4 & SL & 15.8 & 5.3 & 7.7 & 57.6 & 0.67 & 49 & 3.32 & 1.19 & 0.09 & 0.004 \\
\hline 17 & 80 & 2.3 & SL & 16.5 & 8.4 & 6.9 & 62 & 0.56 & 56 & 3.84 & 1.2 & 0.19 & 0.004 \\
\hline 18 & 110 & 10.8 & SL & 11.4 & 6.2 & 12.6 & 43 & 0.48 & 56 & 3.55 & 1.22 & 0.03 & 0.002 \\
\hline 19 & 140 & 13.6 & SL & 4.4 & 2.3 & 13.7 & 78.3 & 0.07 & 63 & 4.41 & 1.23 & 0.31 & 0.004 \\
\hline 20 & 120 & 5.9 & SL & 9.6 & 5.3 & 4.6 & 71 & 0.86 & 63 & 3.66 & 1.53 & 0.17 & 0.002 \\
\hline 21 & 120 & 3.7 & SL & 11.3 & 6.2 & 8.7 & 42 & 0.79 & 78.3 & 3.67 & 1.55 & 0.1 & 0.002 \\
\hline 22 & 125 & 0.3 & SL & 6.3 & 1.5 & 3 & 49 & 0.44 & 171.2 & 3.69 & 1.46 & 0.12 & 0.004 \\
\hline 23 & 120 & 3.8 & SL & 7.5 & 9.9 & 8.8 & 49 & 0.34 & 148.4 & 4.13 & 1.69 & 0.15 & 0.003 \\
\hline 24 & 110 & 0.6 & SL & 9.4 & 7.5 & 4.4 & 49 & 0.51 & 126 & 5.37 & 1.71 & 0.25 & 0.061 \\
\hline 25 & 85 & 6.7 & SL & 10.9 & 6.1 & 4.5 & 42 & 0.63 & 194.3 & 8.66 & 1.57 & 0.01 & 0.003 \\
\hline 26 & 110 & 8.8 & SL & 15.2 & 7.4 & 6.6 & 56 & 0.78 & 232.1 & 5.24 & 1.61 & 0.01 & 0.004 \\
\hline 27 & 100 & 11.6 & SL & 10.5 & 7.9 & 17 & 49 & 0.52 & 70 & 12.35 & 1.9 & 0.01 & 0.002 \\
\hline 28 & 120 & 4.1 & SL & 13.3 & 11.3 & 9.2 & 71 & 0.42 & 61.8 & 6.73 & 1.79 & 0.01 & 0.003 \\
\hline 29 & 120 & 4 & SL & 13.3 & 7.9 & 9.1 & 78 & 0.48 & 232.1 & 5.38 & 1.83 & 0.1 & 0.002 \\
\hline 30 & 120 & 10.2 & LS & 4.7 & 3.6 & 6.6 & 71 & 0.68 & 112.8 & 5.43 & 1.97 & 0.19 & 0.002 \\
\hline 31 & 120 & 2.8 & $\overline{S L}$ & 11.3 & 6 & 7.4 & 63 & 0.53 & 45.6 & 8.13 & $\begin{array}{l}1.9 \\
\end{array}$ & 0.01 & 0.004 \\
\hline 32 & 125 & 10.7 & $\overline{S L}$ & 10.3 & 5.9 & 14.8 & 78 & 0.18 & 213.1 & 7.04 & 1.9 & 0.01 & 0.002 \\
\hline 33 & 90 & 3.6 & SL & 18.4 & 14.3 & 5.2 & 63 & 0.12 & 315 & 1.28 & 0.06 & 0.17 & 0.004 \\
\hline 34 & 70 & 9.7 & SL & 16.9 & 14.3 & 6.3 & 70 & 0.11 & 407.4 & 0.51 & 0.17 & 0.06 & 0.002 \\
\hline 35 & 120 & 1.7 & SL & 10 & 8.9 & 4 & 70 & 0.07 & 342.4 & 0.5 & 0.13 & 0.01 & 0.002 \\
\hline 36 & 110 & 2.5 & SL & 14.1 & 6.5 & 6.1 & 56 & 0.44 & 173.6 & 1.49 & 0.25 & 0.14 & 0.003 \\
\hline 37 & 120 & 6.4 & SL & 7.3 & 8.2 & 9.5 & 56 & 0.64 & $\begin{array}{l}99.2 \\
\end{array}$ & 1.13 & 0.18 & 0.16 & 0.003 \\
\hline 38 & 80 & 11.5 & SL & 10.3 & 11.8 & 15.8 & 28 & 0.41 & 360.9 & 1.58 & 0.28 & 0.01 & 0.003 \\
\hline 39 & 110 & 2.5 & SL & 11.4 & 6.2 & 4 & 42 & 0.17 & 252 & 0.94 & 0.21 & 0.01 & 0.004 \\
\hline 40 & 115 & 6.3 & SL & 10.4 & 8.2 & 3.7 & 49 & 0.06 & 296.8 & 1.91 & 0.13 & 0.14 & 0.003 \\
\hline 41 & 110 & 15.9 & SL & 16.1 & 8.4 & 8.2 & 56 & 0.1 & 315 & 0.92 & 0.18 & 0.01 & 0.003 \\
\hline 42 & 100 & 12.3 & SL & 10.9 & 6.2 & 6.3 & 63 & 0.12 & 225.5 & 0.47 & 0.1 & 0.03 & 0.004 \\
\hline 43 & 75 & 4.9 & SL & 23.2 & 10.9 & 10 & 49 & 0.74 & 28.2 & 2.41 & 0.62 & 0.27 & 0.004 \\
\hline 44 & 100 & 9.4 & SL & 13.4 & 7 & 13.4 & 70 & 0.21 & 315 & 0.92 & 0.17 & 0.1 & 0.003 \\
\hline 45 & 100 & 3.3 & SL & 18.3 & 10.3 & 8.3 & 35 & 0.17 & 333.2 & 0.49 & 0.15 & 0.26 & 0.004 \\
\hline 46 & 110 & 6.6 & SL & 14.3 & 10.2 & 4 & 35 & 0.6 & 199.4 & 1.35 & 0.28 & 0.22 & 0.003 \\
\hline 47 & 90 & 11.9 & SL & 12.3 & 7 & 19.5 & 21 & 0.12 & 225.5 & 1.23 & 0.31 & 0.15 & 0.002 \\
\hline 48 & 90 & 10.8 & SL & 12.3 & 5 & 10.4 & 31.5 & 0.36 & 260.9 & 1.19 & 0.34 & 0.23 & 0.002 \\
\hline 49 & 100 & 9.1 & SL & 12.3 & 5 & 23 & 63 & 0.36 & 173.6 & 1.89 & 0.43 & 0.18 & 0.004 \\
\hline 50 & 100 & 5.3 & LS & 12.7 & 6.3 & 6.5 & 56 & 0.77 & 83.4 & 2.2 & 0.62 & 0.14 & 0.003 \\
\hline 51 & 90 & 13.8 & SL & 13.1 & 5.5 & 8.7 & 56 & 0.34 & 123.5 & 1.21 & 0.59 & 0.15 & 0.003 \\
\hline
\end{tabular}


Table 4 Cont.

\begin{tabular}{|l|l|l|l|l|l|l|l|l|l|l|l|l|l|}
\hline No & $\begin{array}{l}\text { Depth } \\
(\mathbf{c m})\end{array}$ & $\begin{array}{l}\text { EC } \\
\text { dS m }^{-1}\end{array}$ & Texture* & $\begin{array}{l}\mathbf{C a C O}_{\mathbf{3}} \\
\mathbf{\%}\end{array}$ & $\begin{array}{l}\text { Gyp. } \\
\mathbf{\%}\end{array}$ & $\mathbf{E S P}$ & $\begin{array}{l}\mathbf{N} \\
* *\end{array}$ & $\begin{array}{l}\mathbf{P} \\
* *\end{array}$ & $\begin{array}{l}\mathbf{K} \\
* *\end{array}$ & $\begin{array}{l}\mathbf{F e} \\
* *\end{array}$ & $\begin{array}{l}\text { Mn } \\
* *\end{array}$ & $\begin{array}{l}\mathbf{Z n} \\
* *\end{array}$ & $\begin{array}{l}\mathbf{C u} \\
* *\end{array}$ \\
\hline 52 & 100 & 7.3 & LS & 12.8 & 9.3 & 12 & 56 & 0.09 & 216.8 & 6.95 & 0.41 & 0.25 & 0.004 \\
\hline 53 & 90 & 3 & SL & 11.5 & 7.4 & 8 & 56 & 0.6 & 416.8 & 1.87 & 0.51 & 0.23 & 0.006 \\
\hline 54 & 65 & 3.5 & LS & 19 & 5.5 & 8.6 & 49 & 0.6 & 190.8 & 3.4 & 1.83 & 0.23 & 0.004 \\
\hline 55 & 90 & 5.7 & LS & 13.5 & 7.2 & 10.7 & 56 & 0.13 & 287.8 & 2.89 & 0.57 & 0.18 & 0.004 \\
\hline 56 & 60 & 11.8 & SL & 10.3 & 8.8 & 15.6 & 65 & 0.2 & 360.8 & 2.64 & 0.55 & 0.29 & 0.003 \\
\hline 57 & 60 & 3.3 & LS & 14.6 & 11 & 7 & 79 & 0.72 & 234.3 & 2.59 & 0.73 & 0.38 & 0.002 \\
\hline 58 & 75 & 3.7 & SL & 11 & 10.9 & 7.4 & 49 & 0.75 & 75.6 & 1.31 & 0.74 & 0.24 & 0.002 \\
\hline 59 & 130 & 0.5 & SL & 8.4 & 3.4 & 3.1 & 49 & 0.76 & 107.2 & 1.42 & 0.67 & 0.35 & 0.004 \\
\hline 60 & 140 & 0.7 & SL & 5 & 6.2 & 3.6 & 49 & 0.48 & 360.8 & 1.59 & 0.68 & 0.38 & 0.004 \\
\hline 61 & 140 & 0.4 & SL & 6 & 8.4 & 4 & 49 & 0.65 & 287.8 & 2.52 & 0.69 & 0.41 & 0.003 \\
\hline 62 & 140 & 0.7 & SL & 10 & 5.5 & 3.3 & 49 & 1.28 & 252 & 1.58 & 0.66 & 0.28 & 0.185 \\
\hline 63 & 130 & 0.6 & SL & 8.3 & 4.5 & 3.9 & 56 & 0.41 & 342.4 & 1.49 & 0.97 & 0.35 & 0.006 \\
\hline 64 & 60 & 0.3 & LS & 10.7 & 7.5 & 3.4 & 63 & 1.43 & 140 & 1.52 & 0.73 & 0.38 & 0.006 \\
\hline 65 & 140 & 1.9 & LS & 4.4 & 5.3 & 4 & 49 & 0.71 & 165.2 & 3.34 & 0.76 & 0.35 & 0.003 \\
\hline 66 & 140 & 1 & SL & 9.4 & 5.5 & 3.8 & 42 & 1 & 140 & 1.01 & 0.75 & 0.26 & 0.006 \\
\hline 67 & 85 & 4.4 & SL & 14 & 13.5 & 8 & 70 & 0.48 & 315 & 1.11 & 0.76 & 0.17 & 0.002 \\
\hline 68 & 90 & 1.7 & LS & 13.1 & 9.2 & 3.4 & 56 & 0.32 & 269.8 & 4.89 & 0.9 & 0.18 & 0.004 \\
\hline 69 & 120 & 2.1 & LS & 9.6 & 7.5 & 2.6 & 63 & 0.66 & 216.8 & 7.99 & 1.19 & 0.3 & 0.002 \\
\hline 70 & 90 & 2.9 & SL & 10.1 & 8.4 & 3.8 & 56 & 0.85 & 156.7 & 1.74 & 0.89 & 0.3 & 0.002 \\
\hline 71 & 95 & 9.9 & LS & 11.4 & 6.6 & 9.2 & 63 & 0.62 & 173.6 & 3.25 & 1.01 & 0.24 & 0.006 \\
\hline 72 & 110 & 2.8 & LS & 14 & 5.6 & 12.9 & 70 & 0.7 & 243.1 & 1.14 & 0.92 & 0.13 & 0.002 \\
\hline
\end{tabular}

* SL: Sandy Loam LS: Loamy Sand

** macro and micro nutrients in $\mathrm{mg} \mathrm{kg}^{-1}$

\section{AP112 unit}

This soil is undulating topography belong to alluvial plain landscape and represented by 7 soil profiles Nos. 3, 6, 7, 8, 15, 18 and 27 .The soil texture vary between Loamy Sand and Sandy Loam, $\mathrm{CaCO}_{3}$ between 4.3 and $11.3 \%$. EC value in $\mathrm{dS} \mathrm{m}^{-1}$ ranged from 2.6 to 11.8 and ESP from 7.0 to 27.6 (Table 4). Soil gypsum content vary between 3.2 and $7.9 \%$.

\section{AP121 unit}

This unit is Almost Flat topography belong to alluvial plain and represented by 4 soil profiles Nos. 67, 68, 69 and 71 .The soil texture vary between Loamy Sand and Sandy Loam, $\mathrm{CaCO}_{3}$ between 9.6 and $14 \%$. EC value in $\mathrm{dS} \mathrm{m}^{-1}$ ranged from 1.7 to 9.8 and ESP from 2.6 to 9.2 (Table 4). Soil gypsum content vary between 6.6 and $13.5 \%$.

\section{AP122 unit}

These soils are undulating topography belong to alluvial plain and represented by 5 soil profiles Nos. 63, 64, 65, 66, and 72 . The soil texture vary between Loamy Sand and Sandy Loam, $\mathrm{CaCO}_{3}$ between 4.3 and $14 \%$. EC value in $\mathrm{dS}$ $\mathrm{m}^{-1}$ ranged from 0.3 to 2.8 and ESP from 3.4 to 12.9 (Table 4). Soil gypsum content vary between 4.5 and $7.5 \%$.

\section{AT111 unit}

These soils are gently undulating topography belong to terraces landscape and represented by 18 soil profiles Nos. 9 , $16,17,21,22,24,25,26,30,31,35,39,41,42,46,48,49$ and 51 .The soil texture vary between Loamy Sand and Sandy Loam, $\mathrm{CaCO}_{3}$ between 4.7 and $16.5 \%$. EC value in $\mathrm{dS} \mathrm{m}{ }^{-1}$ ranged from 0.3 to 15.9 and ESP from 3 to 23 (Table 4). Soil gypsum content vary between 1.5 and $10.2 \%$.

\section{AT112 unit}

This unit is gently undulating topography belong to terraces landscape and represented by 3 soil profiles Nos. 33, 36 and 50 .The soil texture vary between Loamy Sand and Sandy Loam, $\mathrm{CaCO}_{3}$ between 12.7 and $18.4 \%$. EC value in $\mathrm{dS} \mathrm{m}{ }^{-1}$ ranged from 2.5 to 5.3 and ESP from 5.2 to 6.5 (Table 4). Soil gypsum content vary between 6.3 and $14.3 \%$. 


\section{AT113 unit}

This unit is undulating topography belong to terraces landscape and represented by 3 soil profiles Nos. 34,40 and 47 .The soil texture is Sandy Loam, $\mathrm{CaCO}_{3}$ between 10.4 and $16.9 \%$. EC value in $\mathrm{dS} \mathrm{m}^{-1}$ ranged from 6.3 to 11.9 and ESP from 3.7 to 19.5 (Table 4). Soil gypsum content vary between 7.0 and $14.3 \%$.

\section{AT221 unit}

This unit is gently undulating topography belong to terraces landscape and represented by 4 soil profiles Nos. 52, 54, 55 and 62 .The soil texture vary between Loamy Sand and Sandy Loam, $\mathrm{CaCO}_{3}$ between 10.0 and $19.0 \%$. EC value in $\mathrm{dS} \mathrm{m}^{-1}$ ranged from 0.7 to 7.3 and ESP from 3.3 to 12 (Table 4). Soil gypsum content vary between 5.5 and $9.3 \%$.

\section{AT222 unit}

This unit is undulating topography belong to terraces landscape and represented by 6 soil profiles Nos. 57, 58, 59, 60, 61 and 70 .The soil texture vary between Loamy Sand and Sandy Loam, $\mathrm{CaCO}_{3}$ between 5.0 and $14.6 \%$. EC value in $\mathrm{dS} \mathrm{m} \mathrm{m}^{-1}$ ranged from 0.4 to 3.7 and ESP from 3.1 to 7.4 (Table 4). Soil gypsum content vary between 3.3 and 11. $\%$.

\section{AT223 unit}

These soils are undulating topography belong to terraces landscape and represented by 2 soil profiles Nos. 53 and 56 .The soil texture is Sandy Loam, $\mathrm{CaCO}_{3}$ between 10.3 and $11.5 \%$. EC value in $\mathrm{dS} \mathrm{m}^{-1}$ ranged from 3.0 to 11.8 and ESP from 8 to 15.6 (Table 4). Soil gypsum content vary between 7.4 and $8.8 \%$.

\section{Producing thematic maps of the studied area:}

\section{Soil depth map}

The total depth of soil profiles were between 55 and $140 \mathrm{~cm}$ with mean 105 and the standard deviation is 22.89 . Figure 5 indicated that the soils of very deep whereas depth more than $120 \mathrm{~cm}$ cover about 1415 Feddans (15.59\% of the total studied area. The deep soils represented an area of about 4163 Feddans (45.86\% of the total studied area) where as depth is between 100 and $120 \mathrm{~cm}$. the soils of moderately deep were about 3500 Feddans $(38.55 \% \%$ of the total studied area) with depth from 50 to $100 \mathrm{~cm}$.

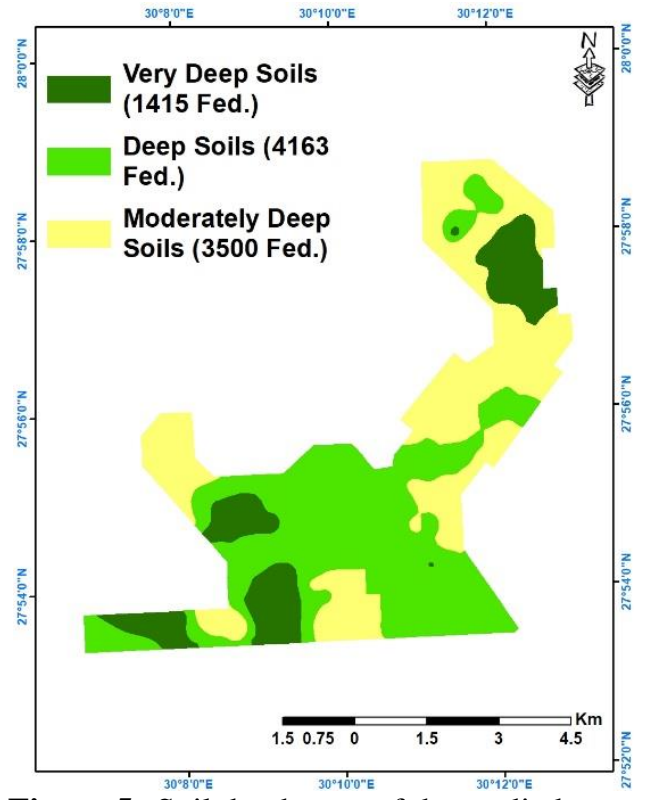

Figure 5:-Soil depth map of the studied area.

\section{Soil texture map}

Figure 6 indicated the dominant soil texture is Sandy Loam that representing an area about 6822 Feddans (75.15\% of the total studied area). On other hand the soils of Loamy Sand were 2256 Feddans (24.85\% of the total studied area). 


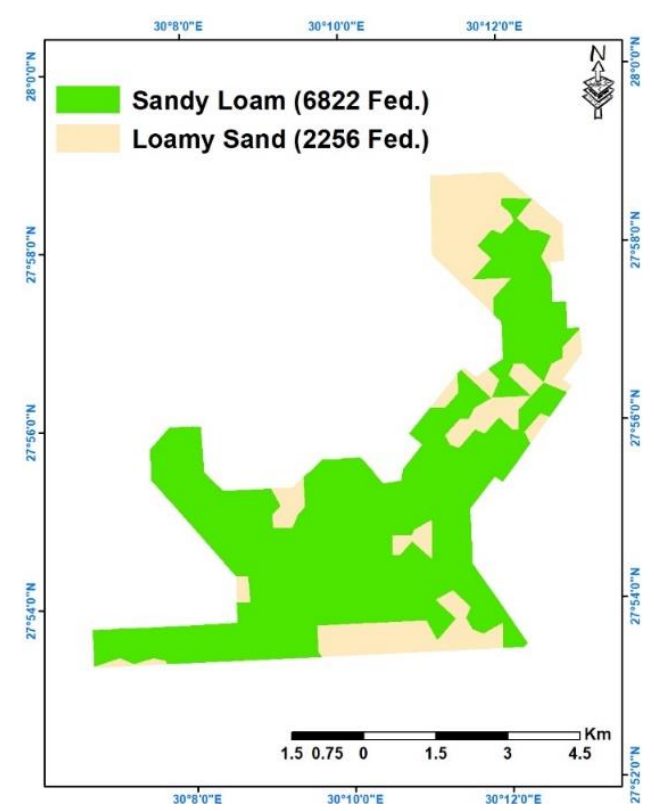

Figure 6:-Soil texture map of the studied area.

\section{Soil salinity map}

Using geo-statistical approach for 72 soil samples for surface layer. ECe values ranged from 0.3 to $15.9 \mathrm{dS} \mathrm{m}^{-1}$ within mean of 5.85. The standard deviation is $4.3 \%$. As indicated in Figure 7 and Table 4 the soils of slightly saline (ECe less than 4) cover an area of about $27.97 \%$ of the total studied area. The soils of moderately saline soils (ECe $4-8$ ) representing an area of about $38.82 \%$ of the total studied area. The highly saline soils (ECe 8 - 16) $33.21 \%$ of the total studied area.

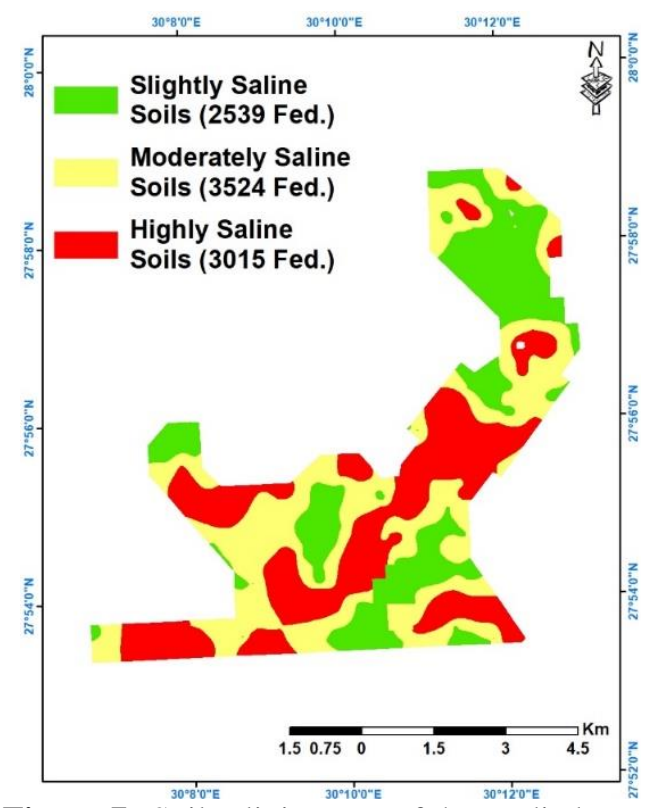

Figure 7:-Soil salinity map of the studied area.

\section{Soil sodicity map}

Exchangeable Sodium Percentage (ESP) ranged between 2.55 and 27.6 for surface layers within mean of 8.66 and the standard deviation is $5.16 \%$. Figure 8 and Table 4 indicated that the soils of non sodic whereas ESP less than 15 
cover about $92.72 \%$ of the total studied area. The soils of sodic-affected areas as ESP more than 15 cover about $7.28 \%$ of the total studied area.

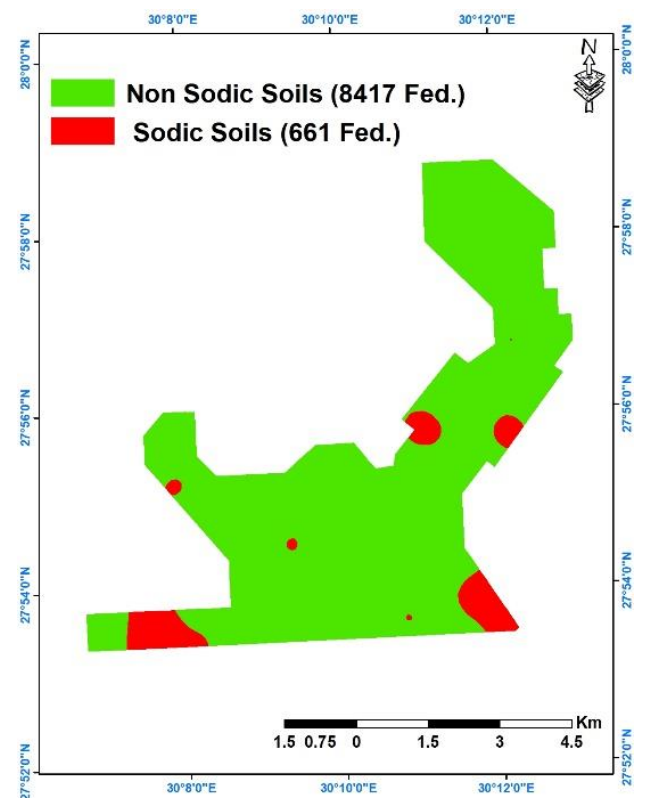

Figure 8:-Soil sodicity map of the studied area.

\section{Soil lime map}

Calcium carbonate was between $2.62 \%$ and $23.2 \%$ with mean $11.28 \%$ and the standard deviation is $11.28 \%$. Figure 9 indicated that the soils of moderately calcareous whereas $\mathrm{CaCO}_{3}$ ranged from 2 to $10 \%$ cover about $29.34 \%$ (2664 Feddans) of the total studied area. The soils of strongly calcareous represented an area of about (6414) Feddans (70.66 \% of the total studied area) where as $\mathrm{CaCO}_{3}$ is between 10 and $25 \%$.

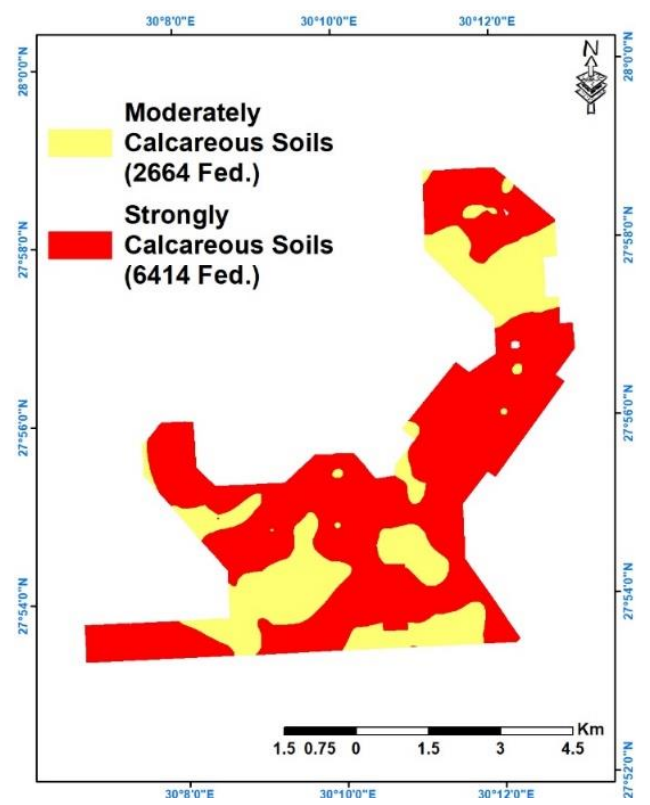

\section{Soil gypsum map}

Figure 9:-Soil lime map of the studied area.

Soil gypsum content was between 1.1 and $14.3 \%$ with mean $7.32 \%$ and the standard deviation is $2.8 \%$. Figure 10 indicated that the soils of Slightly gypsiric whereas gypsum content less than $5 \%$ cover about $5.88 \%$ of the total studied area (533 Feddans). The soils of moderately gypsiric represented an area of about 8545 Feddan (94.12\% of the total studied area) where as gypsum content is between 5 and $15 \%$. 


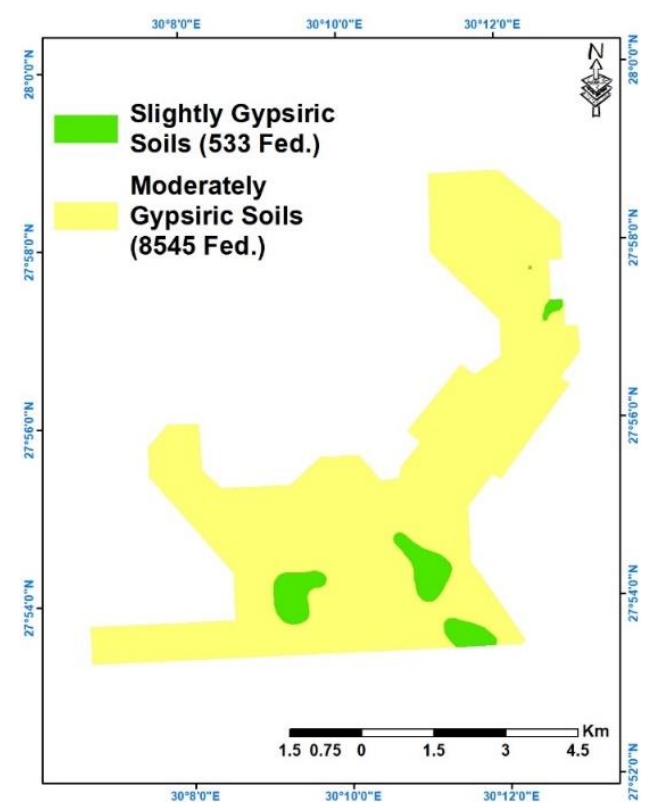

Figure 10:-Soil gypsum map of the studied area.

\section{Land Capability for agriculture}

\section{Current land capability}

Current land capability refers to the capability for a defined land in its present condition without major improvement (FAO, 1976). It may refer to the present use of land, either with existing or improved management practices, or to a different use. The current capability of the studied area is estimated by the present land characteristics and their ratings outlined by Sys et al. (1991). Figure (11) shows a detailed description of the current land capability subclasses in the studied area

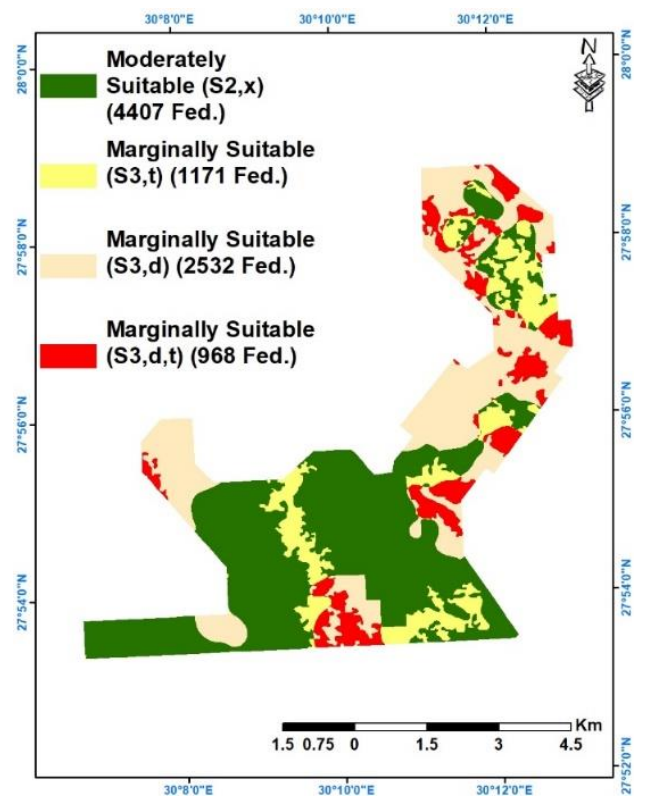

Figure 11:-Current land capability map of the studied area.

Using ARC GIS to overlay all factors i.e. depth, texture, topography, salinity, sodicity, and lime (calcium carbonate) to produce land capability map (Figure 8 ). One order $(S)$ and four subclasses $\left(S_{2} \mathrm{x}, S_{3} t, S_{3} d\right.$ and $\left.S_{3} d, t\right)$ were recognize in the studied soils, the current capability classes is given as follows. 
1. $\mathbf{S}_{2} \mathbf{x}$ : This class occupies an area of about 4407 Feddans, representing $48.55 \%$ of studied area; this subclass representing soils of very deep and deep classes. The soils are flat topography with texture is the only limiting factor.

2. $\quad \mathbf{S}_{\mathbf{3}} \mathbf{t}$ : This subclass occupies an area about 1171 Feddans and representing $12.89 \%$ of total area. The soils are very deep and deep while the most limiting factor is topography (undulating topography).

3. $\mathbf{S}_{\mathbf{3}} \mathbf{d}$ : The soils are moderately deep that representing an area of about 2532 Feddans ( $27.89 \%$ of total area). The depth is the most limiting factor. The recommended cultivated crops are medical and aromatic crops, in addition to fodder crops.

4. $\quad \mathbf{S}_{\mathbf{3}} \mathbf{d}$,t: The soils are moderately deep and have undulating topography with an area 968 Feddans (10.66 \% of total area). The depth and topography are the most limiting factor.

\section{Potential land capability}

for this propose, the land utilization is applicable after executing specified major land improvements as proposed in the current study according to their necessity. In The studied area, land improvements is required to management the severity of limitations exiting in the area under consideration such as; Leveling of undulating surfaces of high and low land area, modern irrigation systems such as drip and sprinkler to save irrigation water and prevent rise of ground water table. Add organic fertilizers, green manures and soil conditioners to increase soil fertility and improve the physical and chemical soil properties.

Potential land capability of studied soils as shown in Figure (12) indicated the existing of one order (S), two subclasses $\left(\mathrm{S}_{2} \mathrm{X}\right.$ and $\left.\mathrm{S}_{3} \mathrm{~d}\right)$ as follows:

1. $S_{2} x$ : This capability subclass covers an area about 5578 Feddans represents $61.45 \%$ of total area (Figure 12 ).

2. $\mathrm{S}_{3} \mathrm{~d}$ : It is covers 3500 Feddans and $38.55 \%$ of total study area. Whereas the depth is the most limiting factor.

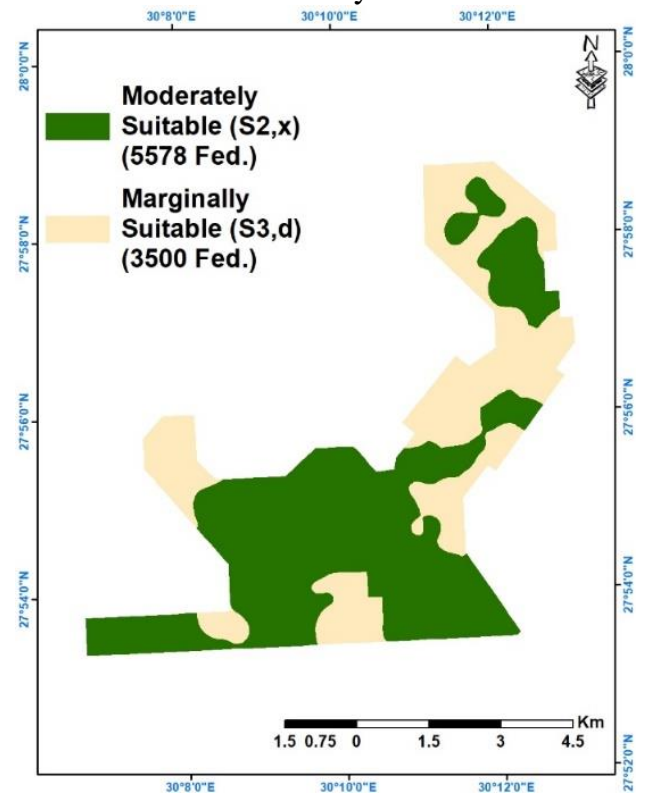

Figure 12:-Potential land capability map of the studied area.

\section{Producing fertility maps of the studied area:}

\section{Available Nitrogen}

The data in Table 4 reveals the available nitrogen content was between 21 and $79 \mathrm{mg} \mathrm{kg}^{-1}$ with mean 56.4 and the standard deviation is 12.77. Figure 13 revealed that the soil of low nitrogen was the smallest area (222 Feddans, 2.45 $\%$ of the total studied area). While the soils of medium were the large class (8856 Feddans, $97.55 \%$ of the total studied area). 


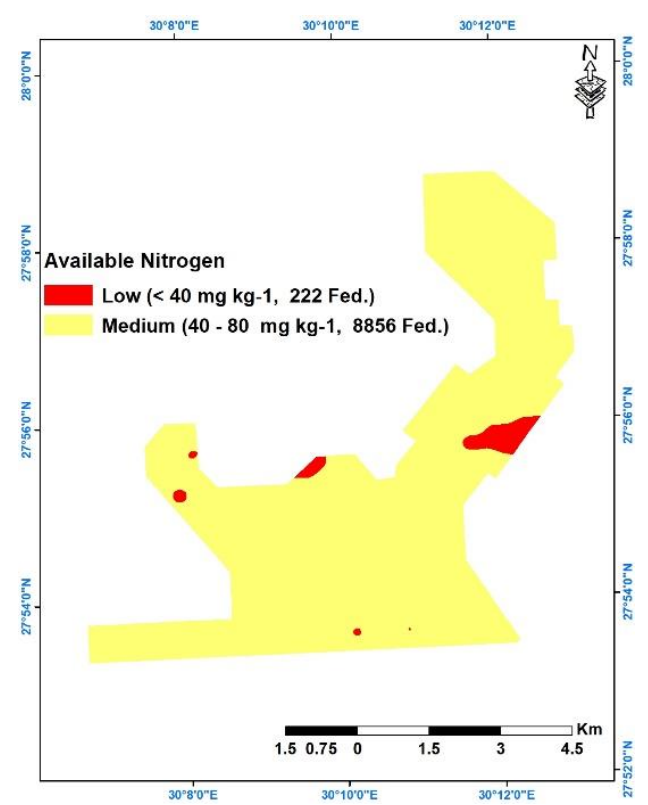

Available Phosphorous

Figure 13:-Soil available nitrogen content

All values for available phosphorous were less than $5 \mathrm{mg} \mathrm{kg}^{-1}$ (Table 4), so all soils is one class (low). Available phosphorous ranged between 0.05 and $3.49 \mathrm{mg} \mathrm{kg}-1$ with mean 0.66 and the standard deviation is 0.56 .

\section{Available Potassium}

The data in Table 4 reveals the available potassium content was between 28.2 and $416.8 \mathrm{mg} \mathrm{kg}^{-1}$ with mean 179.06 and the standard deviation is 104.53. Figure 14 revealed that the soil of low potassium class (6128 Feddans, $67.5 \%$ of the total studied area). While the soils of medium class were (2932 Feddans, $32.3 \%$ of the total studied area). The high class potassium was (18 Feddans, $0.2 \%$ of the total studied area).

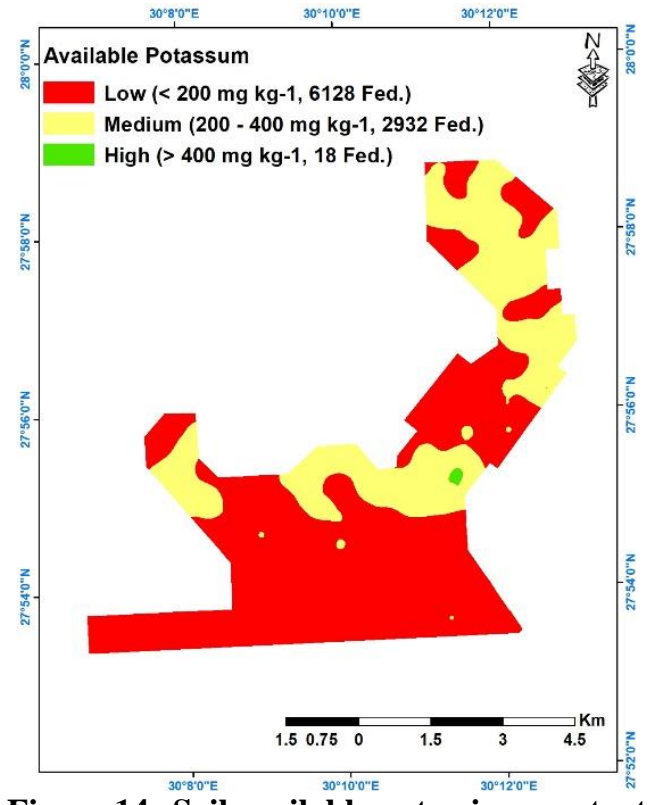

\section{Available Iron}

Figure 14:-Soil available potassium content

Table 4 indicated that the content of available iron was between 0.47 and $12.35 \mathrm{mg} \mathrm{kg}^{-1}$ with mean 3.41 and the standard deviation is 2.93. Figure 15 revealed that the soil of low iron class (6768 Feddans, $74.56 \%$ of the total 
studied area). While the soils of medium class was (2223 Feddans, $24.48 \%$ of the total studied area). The high class iron was ( 87 Feddans, $0.96 \%$ of the total studied area).

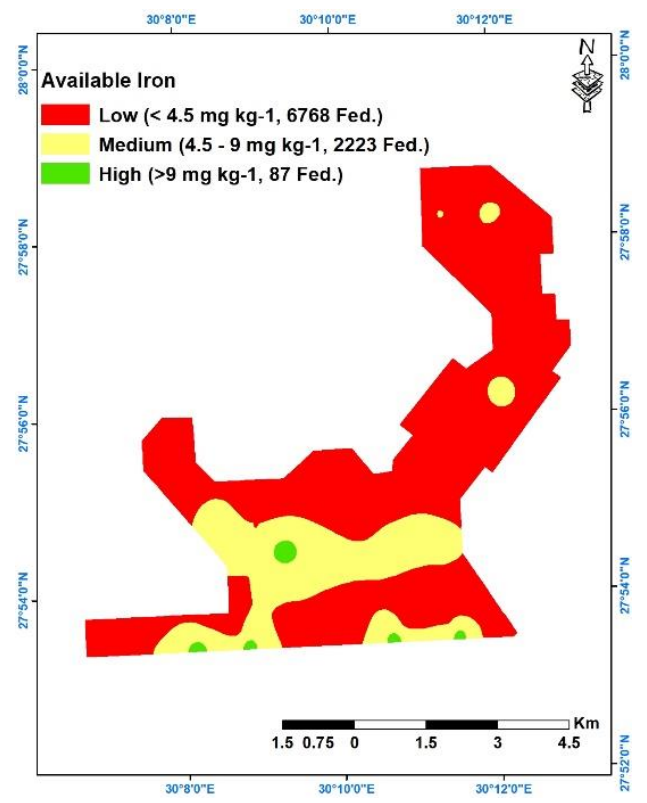

Figure 15:-Soil available iron content

\section{Available Manganese}

The data in Table 4 reveals the available manganese content for all values less than $2 \mathrm{mg} \mathrm{kg}^{-1}$ so all soils are low class. Available manganese ranged between 0.05 and $1.97 \mathrm{mg} \mathrm{kg}^{-1}$ with mean 0.91 and the standard deviation is 0.55 .

\section{Available Zinc}

The data in Table 4 showed the available zinc content for all values less than $1 \mathrm{mg} \mathrm{kg}^{-1}$ so all soils are low class. Available zinc ranged between 0.006 and $0.9 \mathrm{mg} \mathrm{kg}^{-1}$ with mean 0.19 and the standard deviation is 0.18 .

\section{Available Copper}

The data in Table 4 indicated the available copper content for all values less than $0.5 \mathrm{mg} \mathrm{kg}^{-1}$ so all soils are low class. Available copper ranged between 0.002 and $0.18 \mathrm{mg} \mathrm{kg}^{-1}$ with mean 0.011 and the standard deviation is 0.03 .

\section{Water quality for irrigation}

The ground water is the only source for irrigation. The chemical analysis was done to detect the degree of water quality for irrigation (FAO, 1985) as follows:

\begin{tabular}{|l|l|}
\hline TDS $\left(\mathrm{mg} \mathrm{l}^{-1}\right)$ & Water quality \\
\hline $0-600$ & Suitable for irrigation \\
\hline $600-1100$ & Moderately suitable for irrigation \\
\hline $1100-2100$ & Low suitable for irrigation \\
\hline More than 2100 & Not suitable for irrigation unless for highly tolerant salinity crops \\
\hline
\end{tabular}

The water quality for water samples from 9 wells were classified as (C3- S1) class (high salinity and low alkalinity) for all water samples except for samples Nos. 4 and 8 is (C2-S1) (moderately salinity and low alkalinity). On other hand water sample No. 7 is (C4- S1) (very highly saline and low sodium water) not suitable for irrigation purposes where it contains more than $2100 \mathrm{mg} \mathrm{l}^{-1}$ salts (Table 5). 
Table 5:-Chemical properties of irrigation water of some selected wells in the studied area

\begin{tabular}{|c|c|c|c|c|c|c|c|c|c|}
\hline Sample No. & 1 & 2 & 3 & 4 & 5 & 6 & 7 & 8 & 9 \\
\hline pH & 7.6 & 7.6 & 7.3 & 7.2 & 7.4 & 7.2 & 7.35 & 7.6 & 7.6 \\
\hline $\mathrm{EC}\left(\mathrm{dS} \mathrm{cm} \mathrm{cm}^{-1}\right)$ & 2.32 & 2.32 & 2.47 & 1.66 & 2.36 & 1.78 & 3.71 & 1.59 & 2.33 \\
\hline $\operatorname{TDS}\left(\mathrm{mg} \mathrm{l}^{-1}\right)$ & 1486 & 1486 & 1582 & 1062 & 1508 & 1126 & 2372 & 1015 & 1494 \\
\hline SAR & 4.32 & 4.32 & 4.65 & 3.65 & 4.61 & 3.6 & 5.58 & 3.15 & 4.42 \\
\hline $\mathrm{HCO}_{3}\left(\mathrm{mg} \mathrm{l}^{-1}\right)$ & 80.52 & 80.52 & 80.52 & 80.52 & 86.62 & 80.52 & 109.19 & 103.7 & 109.2 \\
\hline $\mathrm{CO}_{3}\left(\mathrm{mg} \mathrm{l}^{-1}\right)$ & - & - & - & - & - & - & - & - & - \\
\hline $\mathrm{Cl}\left(\mathrm{mg} \mathrm{l}^{-1}\right)$ & 373.1 & 373.2 & 414.99 & 330.86 & 409.31 & 318.79 & 691.9 & 318.8 & 493.5 \\
\hline $\mathrm{NO}_{3}\left(\mathrm{mg} \mathrm{l}^{-1}\right)$ & 0.11 & 0.04 & 0.05 & 10.36 & 2.59 & 10.29 & 6.31 & - & - \\
\hline $\mathrm{PO}_{4}\left(\mathrm{mg} \mathrm{l}^{-1}\right)$ & 1.5 & 1.5 & 1.5 & 0 & 0.85 & & - & - & - \\
\hline $\mathrm{SO}_{4}\left(\mathrm{mg} \mathrm{l}^{-1}\right)$ & 505.4 & 505.4 & 524.16 & 345.6 & 485.76 & 374.4 & 693.6 & 306.72 & 459.4 \\
\hline $\mathrm{NH}_{4}\left(\mathrm{mg} \mathrm{l}^{-1}\right)$ & 0.07 & 0.11 & 0.11 & 1.68 & 0 & 0.07 & 2.55 & - & - \\
\hline $\mathrm{Na}^{+}\left(\mathrm{mg} \mathrm{l}^{-1}\right)$ & 240.12 & 240.12 & 264.27 & 184 & 256.22 & 8 & 390.1 & 161 & 264.3 \\
\hline $\mathrm{K}^{+}\left(\mathrm{mg} \mathrm{l}^{-1}\right)$ & 8.95 & 8.59 & 8.99 & 8.99 & 8.99 & 0.23 & 13.2 & 7.82 & 10.16 \\
\hline $\mathrm{Ca}\left(\mathrm{mg} \mathrm{l}^{-1}\right)$ & 90.2 & 107 & 118.4 & 84.6 & 124 & 4.97 & 208.4 & 62 & 101.4 \\
\hline $\operatorname{Mg}\left(\mathrm{mg} \mathrm{l}^{-1}\right)$ & 86.16 & 76.08 & 75.48 & 64.68 & 65.88 & 5.08 & 96.24 & 81.24 & 101.3 \\
\hline $\operatorname{Mn}\left(\mathrm{mg} \mathrm{l}^{-1}\right)$ & 0.02 & 0.5 & 0.5 & 0.081 & 0 & 0.076 & & - & - \\
\hline $\mathrm{Fe}\left(\mathrm{mg} \mathrm{l}^{-1}\right)$ & 0.2 & 0.2 & 0.2 & 0.161 & 0 & 0.084 & 0.021 & - & - \\
\hline $\mathrm{Cu}\left(\mathrm{mg} \mathrm{l}^{-1}\right)$ & 0.2 & 0.2 & 0.2 & 0.049 & 0 & 0.043 & - & - & - \\
\hline $\mathrm{Zn}\left(\mathrm{mg} \mathrm{l}^{-1}\right)$ & 0.2 & 0.2 & 0.2 & 0 & 0 & - & - & - & - \\
\hline $\mathrm{B}\left(\mathrm{mg} \mathrm{l}^{-1}\right)$ & 0.19 & 0.17 & 0.17 & 0.075 & 0 & 0.071 & 0.273 & - & - \\
\hline $\operatorname{Mo}\left(\mathrm{mg} \mathrm{l}^{-1}\right)$ & - & - & - & - & - & - & - & - & - \\
\hline
\end{tabular}

The wells Nos. 1, 2, 3 and 4 are located in the soils of current capability $S_{2} x$, while the wells Nos. 5 and 6 are located in the soils of current capability $S_{3}$ t. On other hand, the wells Nos. 7 and 8 are located in the soils of current capability $S_{3}$ d. Finally, the well No. 9 is located in the soils Current capability $S_{3} d$, t

\section{Proposed crops for the studied area}

Regarding to soil evaluating and water quality the suitable crops for the studied area are sugar beet, fodder beet, date palm, olive, fig, pomegranate, peach, apricot, barely, wheat, sorghum, maize, cowpea and sunflower. In addition, medical and aromatic crops are suitable for such soils. The recommended irrigation systems are sprinkler, drip or pivot systems.

\section{References:-}

1. Arafat, S.M. (2003). The utilization of geoiformation techndegy for agricultural development and management in Egypt Diffuse pollution Conference. Dublin

2. Baker, M.N; Negm, A.Y and Khalial, K.E., (1999): Manual of "Soil, Plant and Water Analysis Methods". Plant Nutrition Dep. Soils, Water and Environ. Institute, Agric. Res. Center. Ministry of Agric. Determination of Soil Fertility Project.

3. Brough, P.A., 1986. Principle of Geographical Information Systems for Land Resources Assessment. Oxford University Press, 194p.

4. CLAC (2018). Central Laboratory for Agricultural Climate (CLAC) website. http: // w.w.w.calc. edu, eg.l

5. Daels, L. 1986. Remote sensing fundamentals. Gent. State Univ., Gent., ITC. J., pp.1-19.

6. EGSA (Egyptian Geological Survey Authority) 1988. "Egyptian General Petroleum Corporation: Geological Map of Egypt", Conoco Coral, printed in Germany by Institute fur Angewandte Geodasie, Berlin, Technische Fachhochschule Berlin, Scale 1:500000.

7. Ehlers, M., M.A. Jadkowski, R.R. Howard and D.E. Brousten (1990). Application of spot data for regional growth analysis and local planning. Photogrametric Engineering and Remote Sensing 56: 175.

8. FAO 1976. A Framework for Land Evaluation. FAO Soil Bulletin, 32. Rome, Italy.

9. FAO 1985. Guidelines: Land Evaluation for irrigated Agriculture. FAO Soils Bulletin No. 55, Rome, Italy. 
10. FAO, 2005. Fertilizer use by crop in Egypt. First version. Food and Agriculture Organization of the United Nations (FAO), Rome, Italy.

11. FAO, 2006. "Guidelines for soil description "fourth edition, FAO, Rome, ISBN 92-5-105521-10.

12. Green, K., 1992. Spatial imagery and GIS: integrated data for natural resource management. J. For. 90: 32-36.

13. Harris, P.M. and S.J. Ventura (1995). The integration of geographic data with remotely sensed imagery to improve classification in an urban area. Phtogromtric Engineering and Remote Sensing 61: 993.

14. Ismail M., Abdel Ghaffar M. K. and Azzam M.A. (2012) GIS application to identify the potential for certain irrigated agriculture uses on some soils in Western Desert, Egypt. The Egyptian Journal of Remote Sensing and Space Sciences 15, 39-51

15. Kalkhan, M.A., T.J. Stohlgren, G.W. Chong, D. lisa and R.M. Reich (2000). A predictive spatial model of plant diversity integration of remote sensed data, GIS and spatial statisties. 8 th Biennial Remote Sensing Application Conference, Albuquerque, NM.

16. Lindsay, W.L. and Norvell, W.A. (1978): Development of a DTPA soil test for zinc, iron, manganese, and copper. J. Soil Sci. Soc. Amer., 42: 421-428.

17. Martin, D. and S.K. Saha (2009). Land evaluation by integrating remote sensing and GIS for cropping system analysis in a watershed . Current Science. 96 (4): 569-575.

18. Page, A.L.; Miller, R.H. and Keeney, D.R. (Eds.) (1982): Methods of Soil Analysis. Part 2. Chemical and Microbiological Properties. 2nd (Ed.). Amer. Soc. of Agronomy. Madison, Wisconsin, USA.

19. Stein, A. (1998). Integrating spatial statistics and remote sensing. INT. J., 19 (9): 1793-1814.

20. Sys, C. and Verheye, W. (1978). An attempt to the evaluation of physical land characteristics for irrigation according to the FAO Framework for land evaluation. Ghent, Belgium., The Netherlands, ITC. J., pp. 66-78.

21. Sys, C., E. Van Ranst and J. Debavey. 1991. Land Evaluation. Part I and S2, Ghent Univ., Ghent Belgium.

22. USDA 2004. Soil Survey Laboratory Methods Manual, Soil Survey Investigation Report No.42: vesion 4.0 November, 2004.

23. Weng, Q. (2001). A remote Sensing-GIS evaluation of Urban expansion and its impact on surface temperature in the Zhujian .Delta, South China. International journal of Urban and Regional Studies 22: 425. 